R. S. Oliveira $\cdot$ M. Vosátka $\cdot$ J. C. Dodd ·

P. M. L. Castro

\title{
Studies on the diversity of arbuscular mycorrhizal fungi and the efficacy of two native isolates in a highly alkaline anthropogenic sediment
}

\begin{abstract}
A field survey of the arbuscular mycorrhizal status of herbaceous plant species was conducted in a highly alkaline anthropogenic sediment resulting from the disposal of waste from an acetylene and polyvinyl chloride factory. Most plant species found at the site were mycorrhizal and the dominant mycotrophic plant species was Conyza bilbaoana. Fungal species richness was assessed by identification of spores extracted from the sediment and from continuously propagated trap pot cultures. All of the six species of arbuscular mycorrhizal fungi (AMF) found were from the genus Glomus. Glomus intraradices and G. mosseae were found in field-collected sediment samples and also occurred most frequently in trap cultures. To test the symbiotic effectiveness of these two fungi, seedlings of C. bilbaoana were inoculated with either native $G$. intraradices BEG163 or G. mosseae BEG198 and non-native $G$. intraradices BEG75 or $G$. mosseae BEG25 isolates in sterile and non-sterile sediment collected from the study site. All four isolates were able to colonise $C$. bilbaoana. However, AMF native to the target sediments were generally more effective than the non-native fungi in promoting plant establishment and growth under highly alkaline conditions. The non-native
\end{abstract}

R. S. Oliveira · P. M. L. Castro ( $₫)$

Escola Superior de Biotecnologia,

Universidade Católica Portuguesa,

Rua Dr. António Bernardino de Almeida,

4200-072 Porto, Portugal

e-mail: plcastro@esb.ucp.pt

Tel.: +351-22-5580059

Fax: +351-22-5090351

M. Vosátka

Institute of Botany,

Academy of Sciences of the Czech Republic,

25243 Pruhonice, Czech Republic

J. C. Dodd

PlantWorks Limited,

1/19 Innovation Building 1000, Kent Science Park,

Sittingbourne, Kent, ME9 8AG, UK
G. intraradices was, however, more effective than the non-native $G$. mosseae. The results of this study suggest the use of adapted AMF as inoculants for phytorestoration of alkaline anthropogenic-stressed sediments.

Keywords High $\mathrm{pH} \cdot$ Industrial sediment - Species richness - Native or non-native arbuscular mycorrhizal fungi $\cdot$ Phytorestoration

\section{Introduction}

Arbuscular mycorrhizal fungi (AMF) are reported to reduce the detrimental effects of soil-associated plant stresses, such as lack of nutrients, organic matter, high salinity or high pH (Sylvia and Williams 1992; Entry et al. 2002). The mycorrhizal symbiosis, therefore, is an important potential strategy for phytorestoration schemes (Dodd et al. 2002; Renker et al. 2004). Van der Heijden et al. (1998a,b) showed that belowground species richness of AMF contributes to the maintenance of plant community diversity and to ecosystem stability. Clearly, multifunctional communities of AMF are important in the establishment and survival of plants in a wide range of habitats (Pfleger et al. 1994; Enkhtuya et al. 2003).

With different levels of compatibility between host plants and AMF (Bever et al. 1996; Klironomos 2003), appropriate isolates of AMF must be selected before field inoculation programmes are undertaken, especially when native or non-native isolates are being considered (Dodd and Thomson 1994). Some studies show that native AMF can grow and function better in soils from which they are isolated, e.g. polluted soils (Enkhtuya et al. 2000), semiarid degraded soils (Caravaca et al. 2003) and agricultural systems (Calvente et al. 2004).

Oliveira et al. (2001) reported the occurrence of arbuscular mycorrhizas on plants growing in a highly alkaline anthropogenic sediment in the Estarreja region of Portugal. Estarreja is one of the most important industrial areas in Portugal, with five decades of activity by the chemical industry. A by-product of this industrial activity 
has been the accumulation of residues in the environment. From 1960 to 1986, the production of acetylene and polyvinyl chloride led to the deposition of 300,000 tons of residues in a 10-ha area within the industrial complex of Estarreja (Balsa et al. 1996). Despite its age, vegetation cover on this site was limited and of low diversity. Extreme alkalinity, high salinity and low soil nutrient levels appeared to be the main constraints. Phytorestoration practices are being adopted to rehabilitate the anthropogenic site.

AMF ecotypes occurring in these sediments are hypothesized to be more adapted to high $\mathrm{pH}$ and salinity than AMF found in non-stressed areas (Sylvia and Williams 1992). The isolation and propagation of these native AMF could improve success in the production of tolerant plants, which can be outplanted into disturbed polluted ecosystems (Vosátka and Dodd 2002).

The objectives of this study were (1) to determine the mycorrhizal status and abundance of the herbaceous plant species found growing on the highly alkaline sediment, (2) to determine species richness of AMF and their frequency of occurrence on the site, and (3) to compare the colonisation and growth benefit of native and non-native AMF isolates on the dominant herbaceous plant species in alkaline sediment from the site.

\section{Materials and methods}

\section{Study site description}

The study site was a 10-ha anthropogenic sedimentation pond in the industrial complex of Estarreja, Northern Portugal $\left(40^{\circ} 46^{\prime} 30^{\prime \prime} \mathrm{N}, 08^{\circ} 35^{\prime} 04^{\prime \prime} \mathrm{W}\right)$, into which had been deposited 300,000 tons of solid waste residues from the production of acetylene and polyvinyl chloride over a 26year period (Balsa et al. 1996). The site had scarce vegetation with a few scattered dwarfed trees (Pinus pinaster Ait. and Salix atrocinerea Brot.) and some patchily distributed herbaceous plant species. The sediment had an electrical conductivity of $5980 \mu \mathrm{S} \mathrm{cm}^{-1}, 4.12 \%$ total organic C, $0.23 \%$ total N, $1.27 \%$ total Ca, $664.2 \mathrm{mg} \mathrm{kg}^{-1}$ total $\mathrm{Na}$ and $11 \mathrm{mg} \mathrm{kg}^{-1}$ Olsen's P (Oliveira et al. 2005). Sediment $\mathrm{pH}\left(\mathrm{H}_{2} \mathrm{O}\right)$ was 11.8 and 12.6 at depths of 5 and $15 \mathrm{~cm}$, respectively.

\section{Mycorrhizal status of herbaceous plants}

Root samples of all herbaceous plant species on the site [except Phragmites australis and Juncus effusus, reported in a previous study (Oliveira et al. 2001)] were collected in June 2001, October 2001, May 2002 and September 2002. Three plants per species, spaced at least $3 \mathrm{~m}$ apart, were chosen randomly within a 1-ha area. Root systems with adhered sediment were carefully harvested to avoid major damage to the feeder roots, sealed in polyethylene bags and stored at $4^{\circ} \mathrm{C}$ for 4 days. Care was taken so that only roots of the sampled plant species were collected. In the laboratory, roots were gently washed to remove adhered sediment. Fine lateral roots were cut into $1-\mathrm{cm}$ pieces and stained using a modified Phillips and Hayman (1970) protocol in which roots were acidified in $2 \%(\mathrm{v} / \mathrm{v}) \mathrm{HCl}$ solution for $24 \mathrm{~h}$ and stained with $0.05 \%(\mathrm{w} / \mathrm{v})$ trypan blue in lactoglycerol heated at $121^{\circ} \mathrm{C}$ for $15 \mathrm{~min}$. Percentage root length colonised (\% RLC) by AMF was assessed by using the gridline intersect method (Giovannetti and Mosse 1980). Stained root pieces were mounted on glass slides for examination with a compound microscope (Olympus BX60, Japan) at $\times 100-400$ magnification range to confirm and record the presence of arbuscules, vesicles, intraradical hyphae, hyphal coils and intraradical spores. Intraradical spore development was confirmed in unstained root pieces examined under a stereomicroscope. When present, dark septate hyphae were recorded. Abundance of each plant species was calculated by counting the number of plants in $10 \times 10-\mathrm{m}$ plots laid out in three zones on the site. The relative abundance for each plant species was calculated as a percentage of total plant abundance.

\section{Species richness of arbuscular mycorrhizal fungi}

Sediment and root cores were sampled on the study site under herbaceous plants from the uppermost $10 \mathrm{~cm}$ by using a soil borer (6 cm diameter) in June 2001 and in October 2001. Fifty individual sediment cores were taken randomly at each sampling time under ten different plant species spaced at least $3 \mathrm{~m}$ apart within a 1-ha area. Samples were kept in sealed polyethylene bags at $4^{\circ} \mathrm{C}$ for 1 week. Each sample was homogenised and spores of AMF were extracted from $100 \mathrm{~g}$ of air-dried subsamples by using a modified Gerdemann and Nicholson (1963) technique for wet sieving and decanting (http://www.kent.ac.uk/bio/beg/ englishhomepage.htm under protocols). Only apparently healthy spores were observed and counted in a Petri dish under a stereomicroscope (Olympus SZ60) at $\times 100$ magnification or less. Identification was based on spore morphology (http://invam.caf.wvu.edu/fungi/taxonomy/speciesID. $\mathrm{htm}$ ) under a stereomicroscope and on diagnostic slides (http://www.kent.ac.uk/bio/beg/englishhomepage.htm under protocols). Data obtained from field-collected samples were used to calculate (1) species richness of AMF, measured as the total number of different species found in all samples; (2) frequency of occurrence, calculated as the number of samples in which a species of AMF was observed as a percentage of total samples; (3) relative abundance, calculated as the number of spores of an AMF species as a percentage of total number of AMF spores; and (4) mean number of spores per $100 \mathrm{~g}$ of air-dried sediment. Because spore identification from field samples is complicated by spore wall deterioration, species richness was corroborated using trap cultures (Dodd et al. 2002). This approach can favour the recovery of spores of AMF species, which may not have sporulated at the times of sampling mentioned above. Seventy-seven trap cultures were set up in October 
2001 using intact plants collected from the study site. The root ball (4-6 cm diameter with attached sediment) of each sample was placed into a 16 (diameter) $\times 12$ (depth)-cm plastic pot, and the remaining volume filled with a $1: 2(\mathrm{v} / \mathrm{v})$ mixture of clinoptilolite (zeolite 1.0-2.5 mm, Chemko, Slovakia) and alkaline sediment collected from the study site (autoclaved twice at $121^{\circ} \mathrm{C}$ for $25 \mathrm{~min}$ on two consecutive days). Seeds of maize (Zea mays L.) and red clover (Trifolium pratense L.) were surface sterilised with $0.5 \%(\mathrm{v} / \mathrm{v}) \mathrm{NaOCl}$ for $15 \mathrm{~min}$ and sown together in the soil around the root ball after the shoots were excised. Clover continued to grow throughout the experiment, whereas new maize seeds were resown every 4 months. Trap cultures were grown in a controlled plant-growth room [16 h photoperiod, $450 \mu \mathrm{mol} \mathrm{m}{ }^{-2} \mathrm{~s}^{-1}$ photosynthetically active radiation (PAR), $17-31^{\circ} \mathrm{C}$ temperature range, 30 $60 \%$ relative humidity range], watered with deionised water as required and supplied with nutrients (without phosphorus) once per week using $1.4 \mathrm{~g} \mathrm{l}^{-1}$ Vitafeed 102 (Vitax, Leicester, UK) with trace elements. Fourteen control trap cultures containing no AMF inocula were incorporated amongst the pots in the growth room to check for airborne or splash contamination during the propagation period. For these pots, autoclaved root balls $\left(121^{\circ} \mathrm{C}\right.$ for $25 \mathrm{~min}$ on two consecutive days) were used. Two $50-\mathrm{cm}^{3}$ cores of substrate were removed from each pot culture after 6, 13, 19 and 25 months. The extraction and taxonomic identification of the species of AMF was conducted as described above for field-collected sediment samples. The data obtained from the trap cultures were used to calculate (1) species richness of AMF, (2) frequency of occurrence over all trap cultures and (3) mean number of spores per $100 \mathrm{~cm}^{3}$ of substrate. The abundance of spores of AMF (based on spore counts) from trap cultures was not measured because it cannot be related to species abundance in the field (Stutz and Morton 1996).

\section{Growth chamber microcosm experiment}

Seeds of the herbaceous plant species (Conyza bilbaoana J. Rémy) were collected from the study site to obtain plants of local provenance and adapted to the sediment. They were surface sterilised with $0.5 \%(\mathrm{v} / \mathrm{v}) \mathrm{NaOCl}$ for $5 \mathrm{~min}$ and pregerminated in plastic trays containing fine sand (AGS 0.5-1.0, Areipor, Bucelas, Portugal) pre autoclaved twice $\left(121^{\circ} \mathrm{C}\right.$ for $\left.25 \mathrm{~min}\right)$ on two consecutive days. Trays were placed in a growth chamber with $16 \mathrm{~h}$ photoperiod, $25^{\circ} \mathrm{C}$ day temperature, $19^{\circ} \mathrm{C}$ night temperature, $90 \%$ relative humidity and $250 \mu \mathrm{mol} \mathrm{m} \mathrm{m}^{-2} \mathrm{~s}^{-1}$ PAR. After 35 days, seedlings of similar size were transplanted singly into 200$\mathrm{cm}^{3}$ pots containing alkaline sediment collected from the upper 5-cm layer on the study site and sieved through a 3$\mathrm{mm}$ mesh. Half of the pots received non-sterile sediment and the other half received sediment sterilised by autoclaving twice at $121^{\circ} \mathrm{C}$ for $25 \mathrm{~min}$ on two consecutive days. Microbial populations from the original non-sterile sediment were reintroduced to the pots containing auto- claved sediment by adding $10 \mathrm{ml}$ of filtrate (Whatman No. 1) from $100 \mathrm{~g}$ of sediment shaken for $2 \mathrm{~h}$ in 11 of autoclaved deionised water. For each sediment (sterile and non-sterile), there were five treatments: non-inoculated controls, plants individually inoculated with Glomus intraradices BEG163, Glomus mosseae BEG198, G. intraradices BEG75 or G. mosseae BEG25. All treatments were replicated six times. G. intraradices BEG163 and $G$. mosseae BEG198 were isolated from the same highly alkaline sediment site, whereas $G$. intraradices BEG75 and $G$. mosseae BEG25 are non-native. G. intraradices BEG75 was originally isolated from a temperate agricultural soil in Switzerland with a $\mathrm{pH}$ of 8.2 , whereas $G$. mosseae BEG25 was originally isolated from a temperate agricultural soil in England with a $\mathrm{pH}$ of 6.6. The two native isolates were propagated in a 1:2(v/v) mixture of clinoptilolite and sterilised alkaline sediment from the study site, whereas the two non-native isolates were cultivated in substrate consisting only of clinoptilolite. Each isolate of AMF was grown separately for 12 months before the beginning of the experiment in multispore pot culture with both $Z$. mays $\mathrm{L}$. and $T$. pratense L. as host plants under the same greenhouse conditions. Each pot of the mycorrhizal treatments received $10 \mathrm{ml}$ of a corresponding inoculum suspension containing colonised root fragments, hyphae and spores placed $2 \mathrm{~cm}$ below the root system. The inoculum suspension of each isolate was prepared by sieving $(710 \mu \mathrm{m}) 450 \mathrm{~cm}^{3}$ of inoculum in $150 \mathrm{ml}$ of deionised water and used to inoculate 12 pots. Every pot from the control treatments received the same volume of another inoculum suspension autoclaved twice $\left(121^{\circ} \mathrm{C}\right.$ for $\left.25 \mathrm{~min}\right)$ on two consecutive days. This suspension was prepared from a mixture of equal parts of the four inocula used. Ten milliliters of a filtrate of the AMF inocula mixture were added to all pots to eliminate differences in microbial populations introduced with the AMF inocula (Koide and Li 1989). The filtrate was prepared as described above for the sediment. The plants were grown in a growth chamber under the same conditions as described above and watered every 2 days with deionised water. Pots with different inoculation treatments were periodically rotated to different positions to minimize differences due to their location in the growth chamber. After a growth period of 4 months, shoots and roots were dried at $70^{\circ} \mathrm{C}$ for $48 \mathrm{~h}$ and weighed. Fresh root samples were stained and \% RLC by AMF determined as described above for the field-collected root samples.

\section{Statistical analysis}

All the data from laboratory microcosm experiment were tested for normality and analysed using one-way analysis of variance (ANOVA). The data from the \% RLC obtained in the sterile sediment were analysed without including the respective non-inoculated control treatment. When a significant $F$ value was obtained $(P<0.05)$, treatment means were compared using Duncan's multiple range test. All 
statistical analyses were performed using the SPSS 11.0.0 software package.

\section{Results}

Mycorrhizal status of herbaceous plants

Nineteen herbaceous plant species belonging to nine families composed the herbaceous plant community on the alkaline sediment (Table 1). Of these, 17 formed an arbuscular mycorrhizal association and two were nonmycorrhizal. Colonisation by AMF was high except for Pteridium aquilinum (L.) Kuhn of the Hypolepidaceae family. Mycorrhizas consisted of all typical structures: arbuscules, vesicles and hyphae. The two non-mycorrhizal plant species were members of Brassicaceae. Intraradical spores were evident in $47 \%$ of the plant species and hyphal coils were occasionally present. Dark septate hyphae were found in roots of three plant species including the nonmycorrhizal Hirschfeldia incana Foss. The values of \% RLC and relative abundance of each plant species varied with sampling date (Tables 1 and 2). C. bilbaoana was the most abundant species in the plant community on all sampling dates, with colonisation by AMF ranging between 66 and $90 \%$.
Species richness of arbuscular mycorrhizal fungi

Three species of AMF were identified directly from fieldcollected sediment samples in October 2001 (Table 3). No spores were found in field sediment samples collected in June 2001. Six species of AMF were found in trap cultures (Table 4). G. intraradices, G. mosseae and G. claroideum spores were detected at each harvest. G. fasciculatum and G. etunicatum spores were detected only at the second harvest. G. geosporum spores appeared only in the last two harvests. The species composition did not vary at the third or fourth harvests (19 and 25 months, respectively). No AMF spores were found in control trap cultures.

The richness of AMF in the alkaline sediment was limited to the genus Glomus. Low spore numbers were found both in field-collected samples and in trap cultures (Tables 3 and 4).

The three species of AMF identified directly from fieldcollected sediment samples had similar relative abundances. G. intraradices and G. mosseae were found both in field-collected samples and with high frequency in trap cultures.

Growth chamber microcosm experiment

Plants grown in non-sterile sediment amended with either of the native AMF isolates (BEG163 and BEG198) pro-

Table 1 Arbuscular mycorrhizal status of the herbaceous plant species found growing in the highly alkaline anthropogenic sediment at four sampling times

\begin{tabular}{|c|c|c|c|c|c|c|}
\hline \multirow[t]{3}{*}{ Family } & \multirow[t]{3}{*}{ Species } & \multicolumn{4}{|c|}{ Root length colonised by AMF (\%) } & \multirow[t]{3}{*}{ Fungal structures } \\
\hline & & June & October & May & September & \\
\hline & & 2001 & 2001 & 2002 & 2002 & \\
\hline \multirow[t]{10}{*}{ Asteraceae } & Andryala integrifolia $\mathrm{L}$. & $69 \pm 4$ & NF & $\mathrm{NF}$ & NF & $\mathrm{A}, \mathrm{V}, \mathrm{H}$ \\
\hline & Aster squamatus (Spreng.) Hieron. & $41 \pm 4$ & NF & NF & $66 \pm 4$ & $\mathrm{~A}, \mathrm{~V}, \mathrm{H}$ \\
\hline & Cirsium vulgare (Savi) Ten. & $66 \pm 4$ & $61 \pm 1$ & $71 \pm 2$ & $69 \pm 5$ & $\mathrm{~A}, \mathrm{~V}, \mathrm{H}, \mathrm{S}$ \\
\hline & C. bilbaoana J. Rémy & $90 \pm 3$ & $66 \pm 1$ & $80 \pm 2$ & $68 \pm 2$ & $\mathrm{~A}, \mathrm{~V}, \mathrm{H}$ \\
\hline & Dittrichia viscosa (L.) Greuter & $25 \pm 4$ & $70 \pm 7$ & $46 \pm 4$ & $36 \pm 3$ & $\mathrm{~A}, \mathrm{~V}, \mathrm{H}, \mathrm{S}$ \\
\hline & Erigeron karvinskianus DC. & $70 \pm 5$ & $60 \pm 3$ & $68 \pm 4$ & $57 \pm 6$ & $\mathrm{~A}, \mathrm{~V}, \mathrm{H}, \mathrm{S}, \mathrm{DSH}$ \\
\hline & Lactuca serriola $\mathrm{L}$. & $49 \pm 6$ & $75 \pm 3$ & NF & $62 \pm 2$ & $\mathrm{~A}, \mathrm{~V}, \mathrm{H}, \mathrm{S}$ \\
\hline & Leontodon rothii Ball. & $57 \pm 2$ & $45 \pm 4$ & $50 \pm 4$ & NF & $\mathrm{A}, \mathrm{V}, \mathrm{H}, \mathrm{C}, \mathrm{S}, \mathrm{DSH}$ \\
\hline & $\begin{array}{l}\text { Pseudognaphalium luteo-album (L.) } \\
\text { Hilliard \& B.L. Burtt }\end{array}$ & $58 \pm 7$ & $64 \pm 5$ & $55 \pm 13$ & $58 \pm 8$ & $\mathrm{~A}, \mathrm{~V}, \mathrm{H}$ \\
\hline & Sonchus tenerrimus L. & $85 \pm 3$ & NF & $58 \pm 3$ & NF & $\mathrm{A}, \mathrm{V}, \mathrm{H}$ \\
\hline \multirow[t]{2}{*}{ Brassicaceae } & Hirschfeldia incana Foss. & 0 & 0 & 0 & 0 & DSH \\
\hline & Lepidium virginicum $\mathrm{L}$. & 0 & NF & NF & NF & - \\
\hline Epilobiaceae & Epilobium parviflorum Schreb. & $72 \pm 4$ & $83 \pm 6$ & $70 \pm 2$ & $62 \pm 5$ & $\mathrm{~A}, \mathrm{~V}, \mathrm{H}, \mathrm{S}$ \\
\hline Geraniaceae & Geranium purpureum Vill. & $50 \pm 7$ & NF & $52 \pm 1$ & NF & $\mathrm{A}, \mathrm{V}, \mathrm{H}, \mathrm{S}$ \\
\hline Hypolepidaceae & Pteridium aquilinum (L.) Kuhn & 0 & 0 & $24 \pm 2$ & $32 \pm 2$ & $\mathrm{~A}, \mathrm{~V}, \mathrm{H}, \mathrm{C}$ \\
\hline Plantaginaceae & Plantago coronopus L. & $65 \pm 3$ & $63 \pm 3$ & NF & $52 \pm 5$ & $\mathrm{~A}, \mathrm{~V}, \mathrm{H}, \mathrm{S}$ \\
\hline Poaceae & Agrostis $\times$ fouilladei P. Fourn. & $45 \pm 3$ & $50 \pm 2$ & $57 \pm 1$ & $51 \pm 1$ & $\mathrm{~A}, \mathrm{~V}, \mathrm{H}$ \\
\hline Solanaceae & Solanum nigrum $\mathrm{L}$. & $37 \pm 10$ & $59 \pm 11$ & NF & NF & $\mathrm{A}, \mathrm{V}, \mathrm{H}$ \\
\hline Valerianaceae & Centranthus calcitrapa Dufr. & $61 \pm 2$ & $\mathrm{NF}$ & $72 \pm 6$ & NF & $\mathrm{A}, \mathrm{V}, \mathrm{H}, \mathrm{S}$ \\
\hline
\end{tabular}

The values are means of three replicates \pm 1 SE. The fungal structures present in mycorrhizas of each plant species are those observed in at least one root sample at any sampling time. $A$ Arbuscules, $V$ vesicles, $H$ hyphae, $C$ hyphal coils, $S$ intraradical spores, $D S H$ dark septate hyphae, $N F$ not found on the site 
Table 2 Relative abundances of arbuscular mycorrhizal and non-mycorrhizal plant species found at the highly alkaline anthropogenic sediment in four sampling times (Raunkiaer 1934)

$C$ Chamaephyte, $H$ hemicryptophyte, $T$ therophyte
Plant species

Life form Relative abundance (\%)

June 2001 October 2001 May 2002 September 2002

\begin{tabular}{llllll}
\hline Arbuscular mycorrhizal & & & & & \\
C. bilbaoana J. Rémy & $\mathrm{T} / \mathrm{H}$ & 35.5 & 40.7 & 31.8 & 39.4 \\
P. luteo-album (L.) Hilliard \& & $\mathrm{H}$ & 22.2 & 19.0 & 19.4 & 33.8 \\
B.L. Burtt & & & & & \\
G. purpureum Vill. & $\mathrm{T}$ & 8.2 & 0 & 18.6 & 0 \\
Agrostis $\times$ fouilladei P. Fourn. & $\mathrm{H}$ & 5.9 & 8.2 & 2.2 & 2.7 \\
P. coronopus L. & $\mathrm{H}$ & 5.3 & 9.4 & 0 & 0.6 \\
C. calcitrapa Dufr. & $\mathrm{T}$ & 5.2 & 0 & 3.1 & 0 \\
L. rothii Ball. & $\mathrm{T}$ & 4.9 & 0.9 & 3.9 & 0 \\
P. aquilinum (L.) Kuhn & $\mathrm{H}$ & 4.8 & 8.5 & 5.9 & 6.7 \\
E. parviflorum Schreb. & $\mathrm{H}$ & 2.8 & 2.9 & 6.3 & 3.8 \\
E. karvinskianus DC. & $\mathrm{C}$ & 2.2 & 3.0 & 2.6 & 3.7 \\
C. vulgare (Savi) Ten. & $\mathrm{H}$ & 0.3 & 0.5 & 0.3 & 0.4 \\
D. viscosa (L.) Greuter & $\mathrm{C}$ & 0.3 & 0.4 & 0.1 & 0.5 \\
A. integrifolia L. & $\mathrm{H}$ & 0.2 & 0 & 0 & 0 \\
A. squamatus (Spreng.) Hieron. & $\mathrm{T} / \mathrm{H}$ & 0.1 & 0 & 0 & 0.2 \\
L. serriola L. & $\mathrm{T} / \mathrm{H}$ & 0.1 & 0.1 & 0 & 0.1 \\
S. tenerrimus L. & $\mathrm{T}$ & 0.1 & 0 & 0.1 & 0 \\
S. nigrum L. & $\mathrm{T} / \mathrm{C}$ & 0.1 & 0.3 & 0 & 0 \\
Total & & 98.2 & 93.9 & 94.3 & 91.9 \\
Non-mycorrhizal & & & & & \\
H. incana Foss. & $\mathrm{H}$ & 1.7 & 6.1 & 5.7 & 8.1 \\
L. virginicum L. & $\mathrm{T}$ & 0.1 & 0 & 0 & 0 \\
Total & & 1.8 & 6.1 & 5.7 & 8.1 \\
\hline
\end{tabular}

duced significantly greater root weight and total plant biomass compared with the plants amended with non-native AMF isolates (BEG75 and BEG25) or controls colonised by undetermined native AMF (Fig. 1). There were no significant differences in shoot dry weight between the treatments, although they were greater in the plants inoculated with the native fungi BEG163 and BEG198.

Plants grown in sterile sediment inoculated with $G$. mosseae BEG25 and uninoculated controls had significantly smaller root dry weight and shoot dry weight when compared with plants in all the other treatments (Fig. 1). Plants inoculated with $G$. intraradices BEG163, G. intraradices BEG75 or G. mosseae BEG198 and grown in sterile sediment produced no significant differences in shoot or root dry weights.

Table 3 Species of AMF identified directly from field-collected sediment samples in October 2001 and their frequency of occurrence, relative abundance and mean number of spores

\begin{tabular}{lcll}
\hline $\begin{array}{l}\text { AMF species } \\
\text { identified }\end{array}$ & $\begin{array}{l}\text { Frequency of } \\
\text { occurrence } \\
(\%)\end{array}$ & $\begin{array}{l}\text { Relative } \\
\text { abundance } \\
(\%)\end{array}$ & $\begin{array}{l}\text { Number of spores } \\
\text { (spores per 100 g } \\
\text { dry sediment) }\end{array}$ \\
G. intraradices & 4 & 31 & 113 \\
G. mosseae & 18 & 26 & 22 \\
G. claroideum & 28 & 43 & 23 \\
\hline
\end{tabular}

The $\%$ RLC of $C$. bilbaoana was significantly greater in non-sterile sediment amended with native AMF isolates (BEG163 and BEG198) and the non-native G. intraradices BEG75 (Fig. 2). There was no significant difference in $\%$ RLC of plants in sediment amended with G. mosseae BEG25, or with no added AMF (background levels). In sterile sediment, \% RLC was significantly greater in plants colonised by the $G$. intraradices isolates (native or nonnative BEG163 and BEG75) followed by the native $G$. mosseae (BEG198) and then the G. mosseae BEG25.

Table 4 Species richness of AMF obtained from trap cultures at each harvest (marked with $\mathrm{x}$ ), their frequency of occurrence and mean number of spores

\begin{tabular}{|c|c|c|c|c|c|c|}
\hline \multirow{2}{*}{$\begin{array}{l}\text { AMF species } \\
\text { identified }\end{array}$} & \multicolumn{4}{|c|}{ Harvest } & \multirow{2}{*}{$\begin{array}{l}\text { Frequency } \\
\text { of occurrence } \\
(\%)\end{array}$} & \multirow{2}{*}{$\begin{array}{l}\text { Number of } \\
\text { spores (spores } \\
\text { per } 100 \mathrm{~cm}^{3} \\
\text { substrate) }\end{array}$} \\
\hline & 1 & 2 & 3 & 4 & & \\
\hline G. intraradices & $\mathrm{x}$ & $\mathrm{x}$ & $\mathrm{x}$ & $\mathrm{x}$ & 15.6 & 87 \\
\hline G. mosseae & $\mathrm{x}$ & $\mathrm{x}$ & $\mathrm{x}$ & $\mathrm{x}$ & 11.7 & 36 \\
\hline G. claroideum & $\mathrm{x}$ & $\mathrm{x}$ & $\mathrm{x}$ & $\mathrm{x}$ & 7.8 & 51 \\
\hline G. etunicatum & & $\mathrm{x}$ & & & 3.9 & 14 \\
\hline G. geosporum & & & $\mathrm{x}$ & $\mathrm{x}$ & 1.3 & 48 \\
\hline G. fasciculatum & & $\mathrm{x}$ & & & 1.3 & 12 \\
\hline Total & 3 & 5 & 4 & 4 & & \\
\hline
\end{tabular}


Fig. 1 Effects of native ( $G$. intraradices BEG163 or $G$. mosseae BEG198) and non-native ( $G$. intraradices BEG75 or G. mosseae BEG25) isolates of AMF on growth of $C$. bilbaoana in sterile (black bars) and nonsterile (dotted bars) alkaline sediment. Values are means \pm 1 SE. The $F$ values of ANOVA for root dry weight, shoot dry weight and total dry weight in non-sterile sediment were

$F_{4,25}=6.5(P<0.01), F_{4,25}=0.9$ $(P>0.05)$ and $F_{425}=5.9$

$(P<0.01)$, respectively. The $F$ values of ANOVA for root dry weight, shoot dry weight and total dry weight in sterile sediment were $F_{4,23}=5.5(P<0.01)$, $F_{4,23}=6.8(P<0.01)$ and $F_{4,23}=6.7(P<0.01)$, respectively. Columns marked with different letters within each sediment (sterile and non-sterile) differed significantly according to Duncan's multiple range test at $P<0.05$. G.i. G. intraradices, G.m. G. mosseae
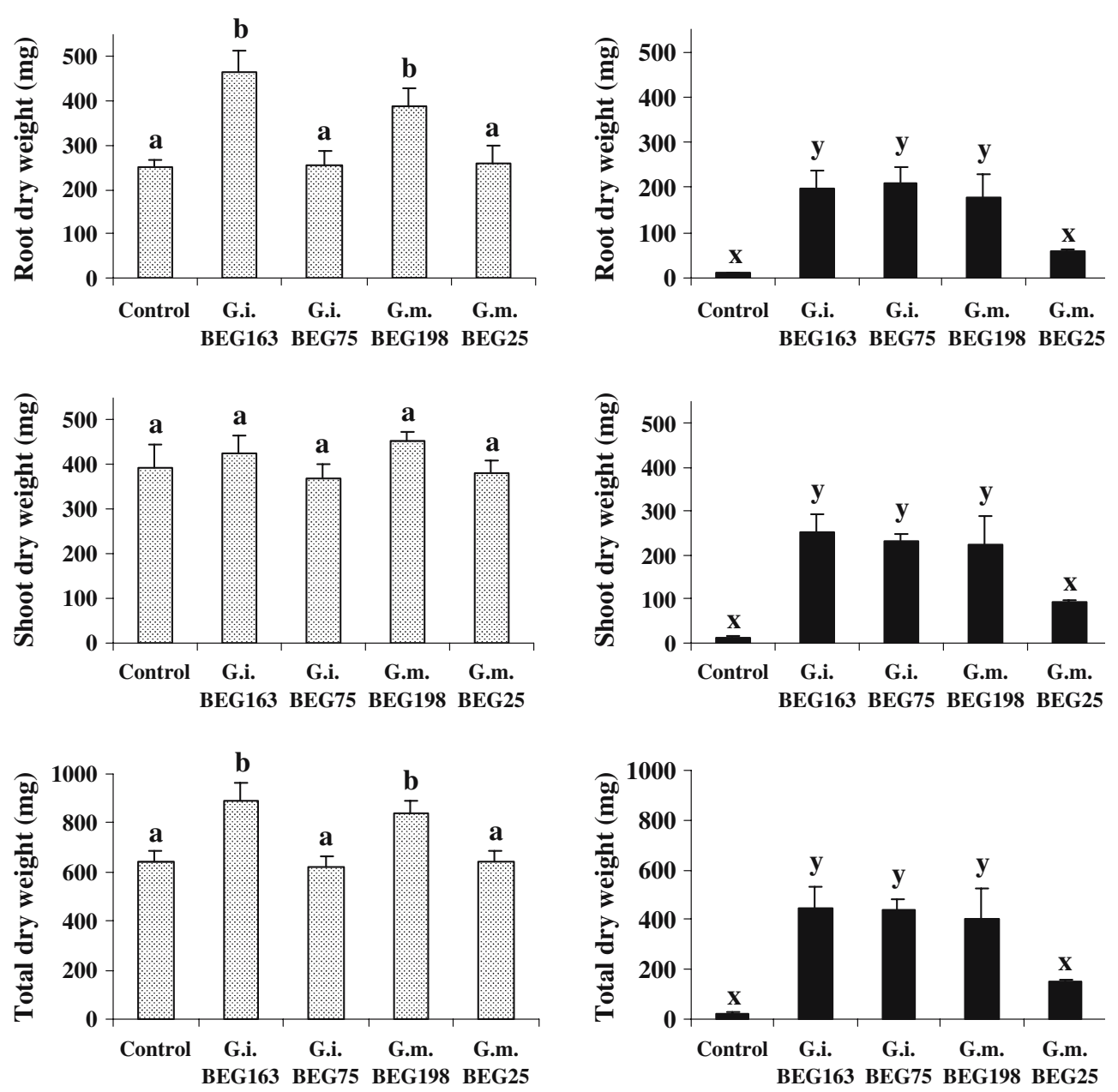

\section{Discussion}

The field survey of established herbaceous plants showed that AMF could tolerate the very high $\mathrm{pH}$ of the anthropogenic sediments and successfully develop a symbiotic mycorrhizal association. Most plant species had high levels of \% RLC at different phenological stages, suggesting a high degree of mycotrophy. Arbuscular mycorrhizal plant

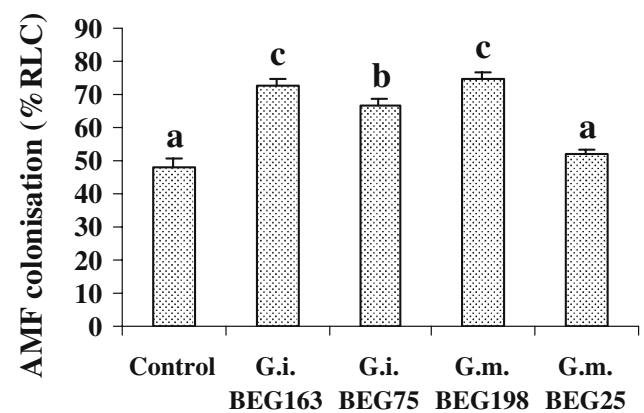

Fig. 2 Percentage root length colonised by AMF of C. bilbaoana plants by native ( $G$. intraradices BEG163 or $G$. mosseae BEG198) and non-native ( $G$. intraradices BEG75 or $G$. mosseae BEG25) isolates of AMF and grown in sterile (black bars) and non-sterile (dotted bars) alkaline sediment. Values are means \pm 1 SE. The $F$ species accounted for 92 to $98 \%$ of total plant abundance. Similar results were obtained by Dodd et al. (2002) in a chalk marl reclamation platform created by the tunnelling of the Channel Tunnel Raillink in UK and by Pawlowska (1991) in a 32-year-old sedimentation basin containing wastes from a soda factory.

Arbuscules were present in all the assessed mycorrhizal plant species, indicating that the symbioses between these



values of ANOVA for sterile and non-sterile sediment were $F_{3,18}=$ $37.5(P<0.0001)$ and $F_{4,25}=48.8(P<0.0001)$, respectively. Columns marked with different letters within each sediment (sterile and nonsterile) differed significantly according to Duncan's multiple range test at $P<0.05$. G.i. G. intraradices, G.m. G. mosseae 
plants and AMF may be functional in the highly alkaline sediment.

Dark septate hyphae were also found in the roots of three plant species including the non-mycorrhizal $H$. incana. Dark septate fungi can influence plant growth (Jumpponen 2001), and their role in these highly alkaline sediments needs further study (Jumpponen and Trappe 1998).

The $\%$ RLC and relative abundance of plant and fungal species were not constant at all samplings, emphasising the importance to take seasonal variation into account when assessing the mycorrhizal status and plant abundance under field conditions (Abbott and Robson 1991; Bever et al. 2001). C. bilbaoana was the dominant herbaceous arbuscular mycorrhizal plant species found growing in the highly alkaline sediment at all sampling times and had the highest levels of \% RLC immediately before flowering of the plant. A peak in colonisation by AMF before flowering was also observed in P. australis growing in the same alkaline sediment (Oliveira et al. 2001) and on wheat (Dodd and Jeffries 1986).

Sediment samples taken directly from the field for direct extraction and identification of spores of AMF were collected in spring and fall seasons (June 2001 and October 2001) because sporulation of AMF species may differ in seasonality (Schultz et al. 1999; Bever et al. 2001). However, no spores of AMF were found in field sediment samples collected in June 2001, whereas spores, which allowed for the identification of three species of AMF, were found in sediment samples collected in October 2001. Douds and Millner (1999) also showed that AMF spore populations were greatest in autumn and at their lowest level during the growing season in areas where there are warm/cold seasons.

The relationship between sporulation and colonisation by AMF varies with different species as well as host and soil nutrient levels (Gazey et al. 1992; Stutz and Morton 1996). In this study, high levels of AMF colonisation and low sporulation were found in the field. This may have been due to inadequate fungal biomass development and poor root development (Gazey et al. 1992) in the alkaline conditions of the sediment or high rates of spore degradation or predation by other soil organisms (Gryndler 2000).

A fungal species may be a significant member of the AMF community, but because of the date of sampling, local environment, or host plant regulation of carbon expenditure may not sporulate (Douds and Millner 1999). To reduce this limitation, AMF trap cultures were established. Using this method, three additional AMF species in sediments were induced to sporulate. Fifty percent of the species of AMF identified from the trap cultures were not found after the first harvest. These observations strengthen the importance of using prolonged trap culture approaches to avoid underestimating the species richness of AMF when using single, short-term, 3- to 6-month trapping regimes (Stutz and Morton 1996; Dodd et al. 2002). Two species of AMF ( $G$. fasciculatum and G. etunicatum) sporulated only at the second harvest. Therefore, results from all sequential samplings must be taken into account for a more complete assessment of the AMF species richness.
There were no differences between the AMF species found at the last two harvests (19 and 25 months), suggesting that this may be the limit of AMF diversity at the site. Molecular biological techniques have indicated greater AMF rDNA sequence variation in the roots of some natural plant communities (e.g. bluebell woodlands in UK) and so not all AMF species may have been able to sporulate (Clapp et al. 1995; Helgason et al. 1998). Furthermore, we used only one type of trap culturing system with a single substrate and a single group of host trap plants and this may influence sporulation of different species of AMF (Bever et al. 1996).

The species richness measured at this study was similar to that found in other studies involving heavy-metalpolluted sites (Pawlowska et al. 1996; Del Val et al. 1999). The size and diversity of the populations of AMF appear to have been reduced by the presence of heavy metals (Del Val et al. 1999). In our study, the very high $\mathrm{pH}$ of the anthropogenic sediment and its salinity may have also restricted the species richness of AMF and possibly allowed only fast-adapting ecotypes to thrive (Turnau et al. 2001).

The AMF community at our site was similar to that found by Vosátka and Dodd (2002) in a survey of AMF in mine spoil banks, metallurgical smelter deposits, sedimentation ponds of fly ash, acid-rain-polluted sites and landfills in central Europe sites, i.e. G. intraradices, G. mosseae, $G$. claroideum, G. geosporum and G. etunicatum.

Constraints on AMF community structure to only Glomus species are not typical. However, similar restrictions in generic diversity were measured in arid environments (Stutz and Morton 1996), semi-arid Mediterranean ecosystems (Ferrol et al. 2004), reclaimed surface mines (Gould and Hendrix 1998), alkaline-saline waste lands (Janardhanan et al. 1994), a chalk marl reclamation platform (Dodd et al. 2002) and several degraded and polluted ecosystems (Vosátka and Dodd 2002).

AMF isolated from the target sediment were very effective in promoting plant growth and establishment of C. bilbaoana under highly alkaline-saline conditions, although all four fungi tested were able to colonise the plants. This indicates that an ecophysiological adaptation of these native AMF ( $G$. intraradices BEG163 and G. mosseae BEG198) to the sediment studied may have occurred (Sylvia and Williams 1992). In another study, Oliveira et al. (unpublished data) found that these two native AMF significantly also improved phosphorus uptake of $C$. bilbaoana plants grown in the same alkaline sediment with low available phosphorus and hence the benefit to the plants is primarily nutritional. It does not preclude, however, the use of fungi isolated from similarly alkaline conditions, which have a broad tolerance to elevated salinity, e.g. G. intraradices BEG75. This would mean that mixtures of AMF could be produced (tuned) aimed at general highly saline-alkaline soils. It was also clear from this study that introduction of an adapted AMF inoculum with a good colonisation capacity can improve the efficacy of the background community of AMF in nonsterile sediment. This study also shows that non-adapted AMF may not function well even when colonising plants to 
high levels in sterile soils with no competition from native AMF. In non-sterile soil, the non-adapted AMF possibly failed to compete successfully and did not contribute more to the overall symbiosis. This is certainly true for the early stage of plant establishment as shown in this study, but plants may still require other species of AMF at different stages of their development (Merryweather and Fitter 1998).

Another possible factor contributing to the success of the two native isolates was that they were maintained under stress (in their original high $\mathrm{pH}$ sediment) during the process of subculturing and it has been demonstrated that AMF can lose their adaptation and stress tolerance when subcultured without the original stress (Malcová et al. 2003a; Rydlová and Vosátka 2003).

The non-native $G$. intraradices BEG75 had the same effect as the two native isolates of AMF in C. bilbaoana grown under sterile conditions (i.e. without the presence of other AMF). However, when inoculated in non-sterile sediments mimicking field conditions, there was no difference between plants inoculated with $G$. intraradices BEG75 and uninoculated controls. This may have been due to competitive interactions with adapted native AMF present in the non-sterilised sediment. It seems therefore that not only adaptation to the abiotic stress of a highly alkaline sediment is important, but also adaptation to biotic interactions with other AMF present in the sediment (Sylvia and Williams 1992). The background colonisation by AMF may have been the reason for the overall better C. bilbaoana growth in non-sterile sediment than in sterile sediment.

There was a significant difference in plant growth promotion between the two non-native isolates tested. $C$. bilbaoana plants inoculated with G. intraradices BEG75 had better growth and higher \% RLC than plants inoculated with $G$. mosseae BEG25 in sterile sediment. In non-sterile sediment, higher levels of \% RLC were obtained in plants inoculated with $G$. intraradices BEG75 when compared with plants inoculated with $G$. mosseae BEG25. This may be explained not only by the possible more aggressive colonisation nature of the $G$. intraradices, but also by the fact that this isolate was originally obtained from a soil with a higher $\mathrm{pH}$ (8.2) than G. mosseae BEG25 (pH 6.6). It is possible that $G$. intraradices BEG75 is more tolerant to high $\mathrm{pH}$ than G. mosseae BEG25. Therefore, G. intraradices $\mathrm{BEG} 75$ is likely to contain requisite genes to tolerate even more extreme conditions with simple natural selection within that gene pool.

In another study, Malcová et al. (2003b) found that $G$. intraradices BEG75 was less effective in promoting plant growth in a lead-contaminated soil when compared with a native $G$. intraradices isolate. It is therefore possible that stress caused by high $\mathrm{pH}$ and salinity is not as inhibitory to AMF as stress caused by heavy metals.

This study shows that there is great potential in using adapted AMF as inoculants for the phytorestoration of anthropogenic stressed alkaline sediments. Phytorestoration with inoculated $C$. bilbaoana plants would benefit the growth and possibly reproduction (Koide 2000) of this plant species, contributing to AMF inoculum build-up in the alkaline sediment. This would favour the invasion by other mycotrophic plant species increasing plant diversity on the site (Vangronsveld et al. 1996; Van der Heijden et al. 1998b).

Another possibility to promote and accelerate restoration in highly alkaline anthropogenic sites is to introduce shrubs and trees inoculated with stress-tolerant AMF and beneficial rhizosphere bacteria.

Acknowledgements Rui Oliveira wishes to thank Fundação para a Ciência e a Tecnologia and Fundo Social Europeu (III Quadro Comunitário de Apoio) for financial support of his Ph.D. studies through grant SFRH/BD/1464/2000. We thank Dr. João Honrado and Dr. Paulo Alves from Departamento de Botânica, Faculdade de Ciências, Universidade do Porto, for help in identification of the plant species. Eng. José Luzes from ERASE and Eng. Helder Paula from CIRES are acknowledged for providing information about the study site and granting permission for plant and sediment sample collection.

\section{References}

Abbott LK, Robson AD (1991) Factors influencing the occurrence of vesicular-arbuscular mycorrhizas. Agric Ecosyst Environ 35:121-150

Balsa ME, Serrão MG, Martins JC, Domingues H, Menino MR (1996) Caracterização do resíduo sólido, terras e águas do Parque de Lamas da Companhia Industrial de Resinas Sintéticas CIRES-Estarreja. Estação Agronómica Nacional, Oeiras

Bever JD, Morton JB, Antonovics J, Schultz PA (1996) Host-dependent sporulation and species diversity of arbuscular mycorrhizal fungi in a mown grassland. J Ecol 84:71-82

Bever JD, Schultz PA, Pringle A, Morton JB (2001) Arbuscular mycorrhizal fungi: more diverse than meets the eye, and the ecological tale of why. Bioscience 51:923-931

Calvente R, Cano C, Ferrol N, Azcón-Aguilar C, Barea JM (2004) Analysing natural diversity of arbuscular mycorrhizal fungi in olive tree (Olea europaea L.) plantations and assessment of the effectiveness of native fungal isolates as inoculants for commercial cultivars of olive plantlets. Appl Soil Ecol 26:11-19

Caravaca F, Barea JM, Palenzuela J, Figueroa D, Alguacil MM, Roldán A (2003) Establishment of shrub species in a degraded semiarid site after inoculation with native or allochthonous arbuscular mycorrhizal fungi. Appl Soil Ecol 22:103-111

Clapp JP, Young JPW, Merryweather JW, Fitter AH (1995) Diversity of fungal symbionts in arbuscular mycorrhizas from a natural community. New Phytol 130:259-265

Del Val C, Barea JM, Azcón-Aguilar C (1999) Diversity of arbuscular mycorrhizal fungus populations in heavy-metal-contaminated soils. Appl Environ Microbiol 65:718-723

Dodd JC, Jeffries P (1986) Early development of vesicular-arbuscular mycorrhizas in autumn-sown cereals. Soil Biol Biochem 18:149-154

Dodd JC, Thomson BD (1994) The screening and selection of inoculant arbuscular-mycorrhizal and ectomycorrhizal fungi. Plant Soil 159:149-158

Dodd JC, Dougall TA, Clapp JP, Jeffries P (2002) The role of arbuscular mycorrhizal fungi in plant community establishment at Samphire Hoe, Kent, UK - the reclamation platform created during the building of the Channel tunnel between France and the UK. Biodivers Conserv 11:39-58

Douds DD, Millner PD (1999) Biodiversity of arbuscular mycorrhizal fungi in agroecosystems. Agric Ecosyst Environ 74:7793 
Enkhtuya B, Rydlová J, Vosátka M (2000) Effectiveness of indigenous and non-indigenous isolates of arbuscular mycorrhizal fungi in soils from degraded ecosystems and man-made habitats. Appl Soil Ecol 14:201-211

Enkhtuya B, Óskarsson Ú, Dodd JC, Vosátka M (2003) Inoculation of grass and tree seedlings used for reclaiming eroded areas in Iceland with mycorrhizal fungi. Folia Geobot 38:209-222

Entry JA, Rygiewicz PT, Watrud LS, Donnelly PK (2002) Influence of adverse soil conditions on the formation and function of arbuscular mycorrhizas. Adv Environ Res 7:123-138

Ferrol N, Calvente R, Cano C, Barea JM, Azcón-Aguilar C (2004) Analysing arbuscular mycorrhizal fungal diversity in shrubassociated resource islands from a desertification-threatened semiarid Mediterranean ecosystem. Appl Soil Ecol 25:123-133

Gazey C, Abbott LK, Robson AD (1992) The rate of development of mycorrhizas affects the onset of sporulation and production of external hyphae by two species of Acaulospora. Mycol Res 96:643-650

Gerdemann JW, Nicholson TH (1963) Spores of mycorrhizal Endogone species extracted from the soil by wet sieving and decanting. Trans Br Mycol Soc 46:235-244

Giovannetti M, Mosse B (1980) An evaluation of techniques for measuring vesicular arbuscular mycorrhizal infection in roots. New Phytol 84:489-500

Gould AB, Hendrix JW (1998) Relationship of mycorrhizal activity to time following reclamation of surface mine land in western Kentucky. II. Mycorrhizal fungal communities. Can J Bot 76:204-212

Gryndler M (2000) Interactions of arbuscular mycorrhizal fungi with other soil organisms. In: Kapulnik Y, Douds DD (eds) Arbuscular mycorrhizas: physiology and function. Kluwer, Dordrecht, pp 239-262

Helgason T, Daniell TJ, Husband R, Fitter AH, Young JPW (1998) Ploughing up the wood-wide web? Nature 394:431

Janardhanan KK, Khaliq A, Naushin F, Ramaswamy K (1994) Vesicular-arbuscular mycorrhiza in an alkaline usar land ecosystem. Curr Sci 67:465-469

Jumpponen A (2001) Dark septate endophytes - are they mycorrhizal? Mycorrhiza 11:207-211

Jumpponen A, Trappe JM (1998) Dark septate endophytes: a review of facultative biotrophic root-colonizing fungi. New Phytol 140:295-310

Klironomos JN (2003) Variation in plant response to native and exotic arbuscular mycorrhizal fungi. Ecology 84:2292-2301

Koide RT (2000) Mycorrhizal symbiosis and plant reproduction. In: Kapulnik Y, Douds DD (eds) Arbuscular mycorrhizas: physiology and function. Kluwer, Dordrecht, pp 19-46

Koide RT, Li M (1989) Appropriate controls for vesicular-arbuscular mycorrhiza research. New Phytol 111:35-44

Malcová R, Rydlová J, Vosátka M (2003a) Metal-free cultivation of Glomus sp. BEG 140 isolated from Mn-contaminated soil reduces tolerance to $\mathrm{Mn}$. Mycorrhiza 13:151-157

Malcová R, Vosátka M, Gryndler M (2003b) Effects of inoculation with Glomus intraradices on lead uptake by Zea mays L. and Agrostis capillaris L. Appl Soil Ecol 23:55-67

Merryweather J, Fitter A (1998) The arbuscular mycorrhizal fungi of Hyacinthoides non-scripta. I. Diversity of fungal taxa. New Phytol 138:117-129

Oliveira RS, Dodd JC, Castro PML (2001) The mycorrhizal status of Phragmites australis in several polluted soils and sediments of an industrialised region of Northern Portugal. Mycorrhiza 10:241-247
Oliveira RS, Castro PML, Dodd JC, Vosátka M (2005) Synergistic effect of Glomus intraradices and Frankia spp. on the growth and stress recovery of Alnus glutinosa in an alkaline anthropogenic sediment. Chemosphere (in press) DOI 10.1016/ j.chemosphere.2005.01.038

Pawlowska TE (1991) Plant mycorrhizae in the sedimentation tanks of the Cracow soda factory. Zesz Nauk Uniw Jagiell Pr Bot 22:163-170

Pawlowska TE, Blaszkowski J, Ruhling A (1996) The mycorrhizal status of plants colonizing a calamine spoil mound in southern Poland. Mycorrhiza 6:499-505

Pfleger FL, Steward EL, Noyd RK (1994) Role of VAM fungi in mine land revegetation. In: Pfleger FL, Linderman RG (eds) Mycorrhizae and plant health. APS, St. Paul, pp 47-82

Phillips JM, Hayman DS (1970) Improved procedures for clearing and staining parasitic and vesicular-arbuscular mycorrhizal fungi for rapid assessment of infection. Trans Br Mycol Soc $55: 158-161$

Raunkiaer C (1934) The life forms of plants. Oxford University Press, Oxford

Renker C, Zobel M, Opik M, Allen MF, Allen EB, Vosátka M, Rydlová J, Buscot F (2004) Structure, dynamics, and restoration of plant communities: do arbuscular mycorrhizae matter? In: Temperton VM, Hobbs R, Nuttle T, Halle S (eds) Assembly rules and restoration ecology. Island Press, Washington, DC, pp 189-229

Rydlová J, Vosátka M (2003) Effect of Glomus intraradices isolated from $\mathrm{Pb}$-contaminated soil on $\mathrm{Pb}$ uptake by Agrostis capillaris is changed by its cultivation in a metal-free substrate. Folia Geobot 38:155-166

Schultz PA, Bever JD, Morton JB (1999) Acaulospora colossica sp. nov. from an old field in North Carolina and morphological comparisons with similar species, A. laevis and A. koskei. Mycologia 91:676-683

Stutz JC, Morton JB (1996) Successive pot cultures reveal high species richness of arbuscular endomycorrhizal fungi in arid ecosystems. Can J Bot 74:1883-1889

Sylvia DM, Williams SE (1992) Vesicular-arbuscular mycorrhizae and environmental stresses. In: Bethlenfalvay GJ, Linderman RG (eds) Mycorrhizae in sustainable agriculture, ASA Spec. Publ. No. 54. ASA, Madison, pp 101-124

Turnau K, Ryszka P, Gianinazzi-Pearson V, van Tuinen D (2001) Identification of arbuscular mycorrhizal fungi in soils and roots of plants colonizing zinc wastes in southern Poland. Mycorrhiza 10:169-174

Van der Heijden MGA, Boller T, Wiemken A, Sanders IR (1998a) Different arbuscular mycorrhizal fungal species are potential determinants of plant community structure. Ecology 79:20822091

Van der Heijden MGA, Klironomos JN, Ursic M, Moutoglis P, Streitwolf-Engel R, Boller T, Wiemken A, Sanders IR (1998b) Mycorrhizal fungal diversity determines plant biodiversity, ecosystem variability and productivity. Nature 396:69-72

Vangronsveld J, Colpaert JV, Van Tichelen KK (1996) Reclamation of a bare industrial area contaminated by non-ferrous metals: physico-chemical and biological evaluation of the durability of soil treatment and revegetation. Environ Pollut 94:131-140

Vosátka M, Dodd JC (2002) Ecological considerations for successful application of arbuscular mycorrhizal fungi inoculum. In: Gianinazzi S, Schuepp H, Barea JM, Haselwandter K (eds) Mycorrhizal technology in agriculture. Birkhauser, Basel, pp 235-247 